\title{
Sedimentologic modelling of the Ap-13 hydrocarbon reservoir
}

\author{
Szabina Grund, János Geiger \\ Department of Geology and Paleontology, Univeristy of Szeged, Szeged
}

Over the years many studies have been conducted to understand the delta system of the Algyo field, many of them dealing with the Ap-13 reservoir. In the present study, therefore, several papers have been reviewed and analyzed to provide the basis for a more detailed description of this reservoir.

A macro-scale sedimentological model was developed using Markov analysis. Golden Software's Surfer 8.1 and Strater were used to construct the maps and to define the vertical sedimentological facies of the A-993 borehole. The mega-scale sedimentological 3-D model and the petrophysical parameters of 144 boreholes were analyzed using the Rockware RockWorks 15 and SPSS software.

It is concluded, when comparing the vertical section of the A-993 borehole (from the core description) with the sand content from the 3-D model at similar depth, considering the results of the embedded Markov model and the 3-D sedimentological model, that the reservoir is a deep-marine sand body, with a sand content less than $55 \%$ and siltstone content of around $30 \%$. It is characterized by the features of proximal middle fan systems.

Key words: Algyő delta, factor analysis, vertical sedimentary facies, 3-D model, prodelta submarine fan

\section{Introduction}

One of the most interesting research areas in Hungary is the Algyó oil field, because of its huge hydrocarbon reserves. The crest of the Algyó high was mapped by seismic and gravity surveys around 1960. It was assumed that the conditions in the thick basin deposits were convenient for hydrocarbon

Addresses: Sz. Grund, J. Geiger: H-6722 Szeged, Egyetem u. 2-6. Hungary e-mail: szabus88@gmail.com

Received: August 28, 2011; accepted: December 16, 2011 
generation, migration and trapping. The focus of exploration turned to relatively deeper layers, which meant dealing with increasing pressure and temperature conditions. This study is focused on the Ap-13 gas cap reservoir, which is situated between 2400-2550 m (TD); its thickness ranges between 4 and $50 \mathrm{~m}$. This reservoir is part of the Szolnok Formation in the Lower Pannonian sequence.

\section{Objective}

The aim of this study was to perform a more detailed sedimentological study of the Ap-13 hydrocarbon reservoir than the previous ones. The available database was used as input for statistical computations, 3-D visualization, and geologic modeling. The importance of this renewed study lies in the prediction of remaining hydrocarbon reserves, and a better understanding of the depositional process.

\section{Brief history of hydrocarbon exploration in the Algyó Field}

Exploration began in the 1960s. The first significant success occurred in 1965, when the Upper Pannonian productive sequence was reached. This field is still the largest hydrocarbon accumulation in Hungary. The A-1 well reached a final depth of $2262 \mathrm{~m}$, which is the top of the Lower Pannonian sequence. At this time the most important research topic aimed at understanding the lithostratigraphic connections and defining the basic genetic features. The new genetic approaches to Neogene sediments in the basin were based on the research of this period (Bérczi 1969; Mucsi 1973). The second phase of exploration (geologic understanding) occurred between 1970 and 1990 (Révész 1976, 1977, 1979, 1980a, 1980b). The main approach was the identification of small-scale heterogeneity using geophysical micrologs and cores. At the end of the 1980s geostatistics began to increase in importance as the analytical method of geologic processes. These early geostastical studies provided the basis for 3-D modeling (Geiger and Komlósi 1991; Geiger and Révész 1992; Geiger and Komlósi 1993, 1995a, 1995b, 1996; Geiger and Kissné 1995).

\section{Brief evaluation history of the Algyó delta system}

The Algyő Field contains both gas and oil. This HC-bearing sequence can be divided into three major parts. In the lowest position is the Szolnok Formation. These sand-mud deposits are turbiditic sand bodies which were derived from prodelta fans. The middle part of the sequence is formed by delta slope sediments, with less favorable reservoir parameters than the other parts. The reservoirs in the upper part belong to the Újfalu Formation, formed by delta plain processes. 
The Pannonian Lake had existed from 12 Ma to 4.5 Ma in the area of the Carpathian Basin, making up a fluvio-lacustrine system. This lake had been charged by rivers from the northwest, with large delta systems similar to those of major recent river systems; thus their significance for the sedimentation process was considerable. Using seismic, magnetostratigraphic and biostratigraphic measurements, Magyar (2010) created a map of the extension of the shelf edge migration through time (Fig. 1).

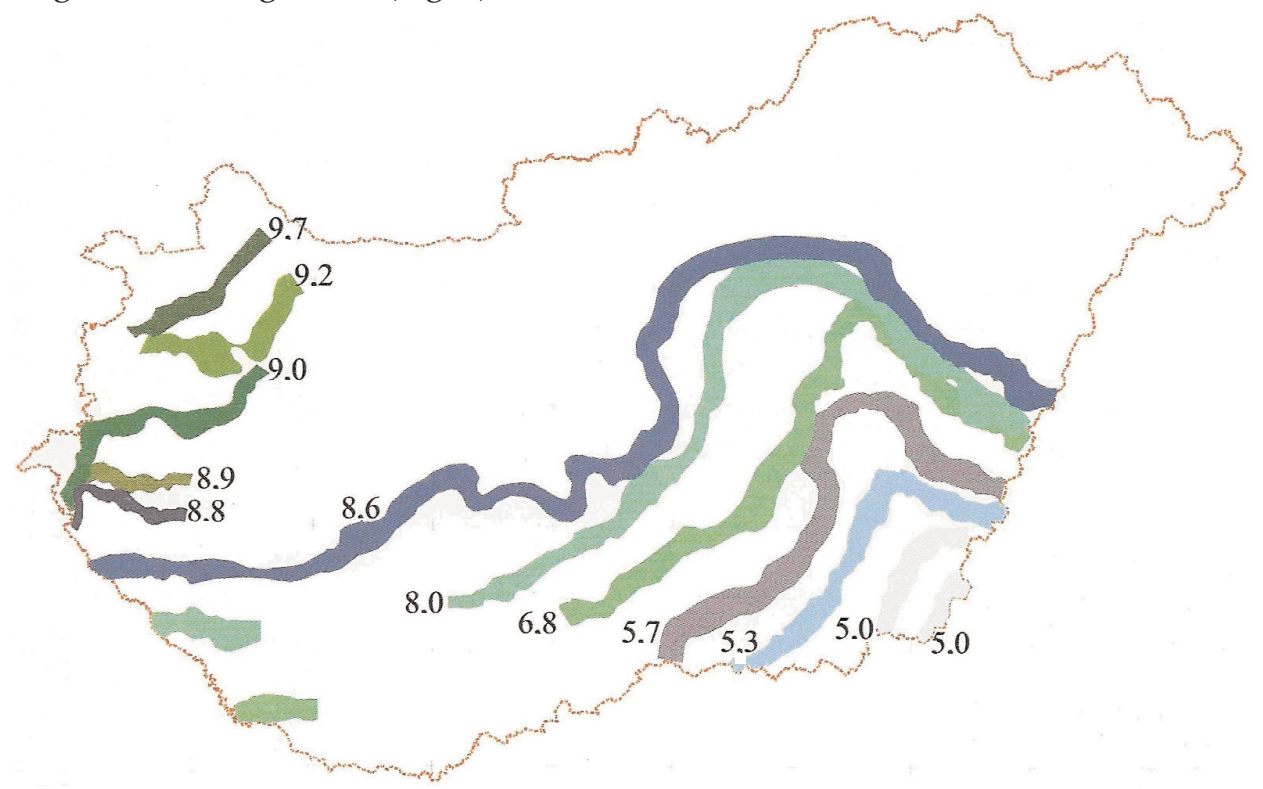

Fig. 1

Extent of the shelf edge (Magyar 2010)

\section{Features of Ap-13 hydrocarbon reservoir (based on former studies)}

The reservoir depth is $2400-2550 \mathrm{~m}$ bmsl. It is a gas-cap hydrocarbon reservoir, showing decreasing thickness from the northeast to south. The greatest vertical thickness is $50 \mathrm{~m}$ and the thinnest occurrence is $3.5 \mathrm{~m}$. The coordinates of this field in EOV (Unified National Projection) are:

Xmin: 585,600; Xmax: 594,800

Ymin: 360,400; Ymax: 372,000

This Algyó Delta sequence is made up of three parts (Fig. 2). In the highest position are the delta front and delta plain facies. The delta slopes occur in the middle part; the deepest position is occupied by the prodelta area with turbidites. The studied reservoir is one of the deepest in this system. This area had been drilled by 144 wells, with accompanying geophysical logs and cores. This study presents the detailed work of a core description from the A-993 well. 


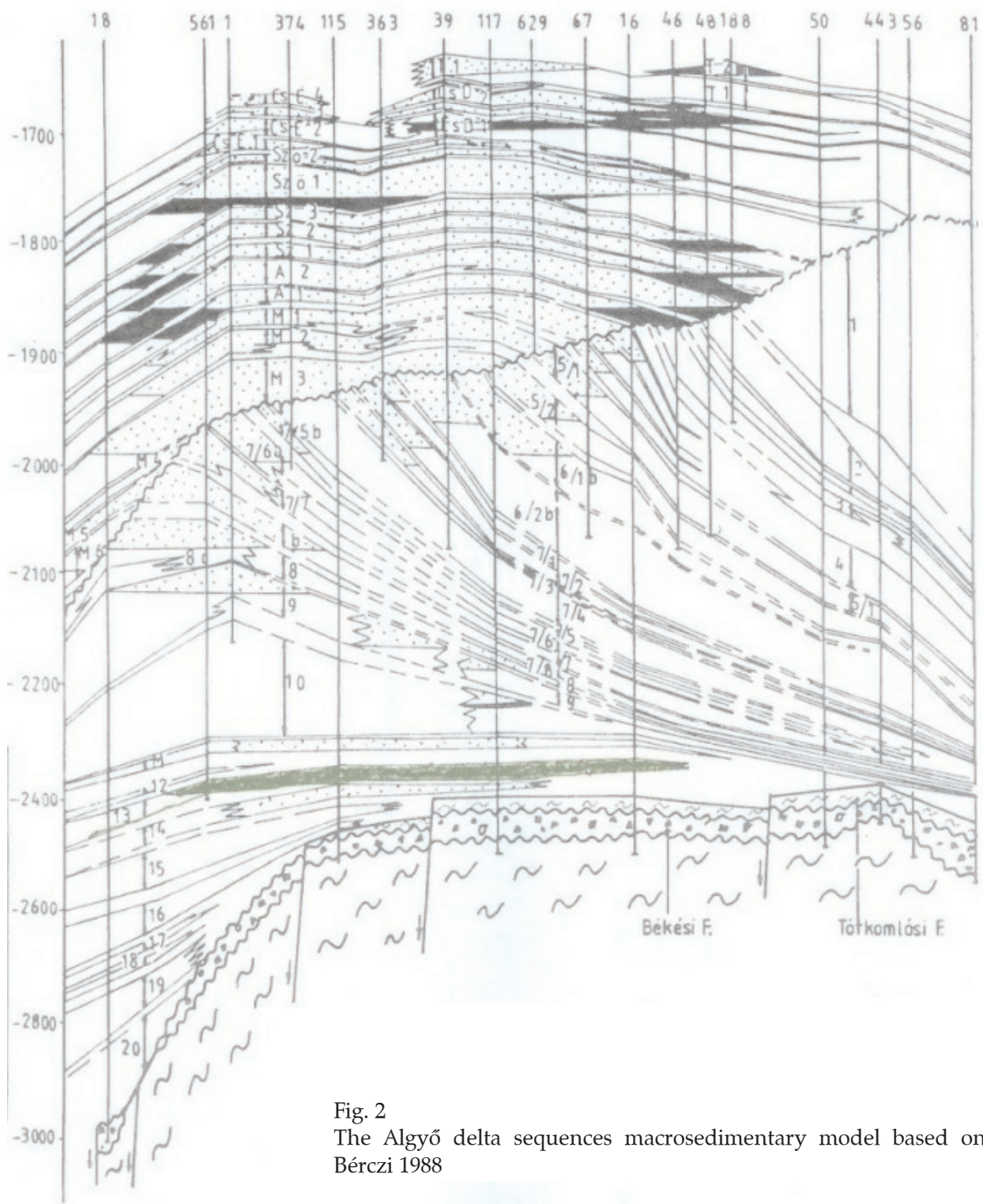

The Ap-13 reservoir was divided into five sections in former studies (Hniszné 1996). These levels were defined by their reservoir properties. Parts "A", "B", "C" and " $\mathrm{D}$ " interfinger with each other. " $\mathrm{B}$ " and " $\mathrm{D}$ " have better reservoir properties; " $\mathrm{C}$ " is variable and complex, and "A" and "E" have poor reservoir parameters (Mucsi and Geiger 1989).

The core material contains fining-upward sequences, and some parts of the Bouma series ("A" sequences with intraclasts, "B", "D" and "E" parts of the series). 


\section{Depositional model of the sand body}

The cored A-922 well provided information for defining the modal sequence, using the Markov analysis method (Mucsi and Geiger 1989). It was possible to determine eight lithological elements.

Based on the previous analysis, the sedimentation cycle model is as follows:

Horizontal layered clay marl $\rightarrow$ unlayered, fine-grained sandstone $\rightarrow$ layered, fine and medium-grained sandstone $\rightarrow$ unlayered, fine-grained sandstone $\rightarrow$ laminated clay-marl.

\section{Applied test methods}

Macroscopic analysis - Core description

To begin with it is necessary to define the formal lithological units and the scale. Facies, in this case, is defined as a rock body with specified characteristics. In the case of sedimentary rocks, it is defined on the basis of color, bedding, compositional texture, fossils and sedimentary structures. The expression "bed" was employed for units of thickness greater than 8-10 cm, distinguished from others by lithology type, grain size, more rarely grain orientation, shape or the change of vertical bedding. If the units are thinner than 8-10 cm, they are called layers. Amalgamation surfaces and sole marks were also defined. To describe the sequence of the sedimentological facies it is important to understand the environment of facies changes (deformation, erosion and deposition) within the structure of the core.

\section{Statistical analysis}

\section{EDA - Exploration Data Analysis}

The study began with the primary analysis of data series, and the computation of basic statistical quantities. This process is considered to be useful in order to obtain a better understanding of the data structure.

It consists of two steps: 1) Determination of summary statistics, and 2) graphic representation of the data.

It provides an overall picture and permits drawing conclusions concerning the data population. The graphic presentation allows the determination of the connections and systems existing between data values; it confirms or rejects certain assumptions and can identify potential problems.

The types of data used are calculated reservoir parameters from geophysical well logs, which were constrained by core measurements (PERM - permeability, FIAP - porosity, SWAP - bound water saturation, HEFF - effective thickness, VSND - sand content, VSHA - shale content). 
$Q-Q$ diagram $/$ plot

In statistics, this is a graphic method for comparing two probability distributions. "Q" stands for quantile. This diagram plots the quantiles against each other. One plot is empirical, showing the features' quantile values, while the theoretical one shows the distribution of data value quantiles and the distribution of theoretic quantiles.

\section{P-P diagram/plot}

This is a probability plot for estimating how tightly two data sets agree with each other, and which plots the two cumulative distribution functions against each other.

For these two plots the following settings were used:

Test distribution:

Proportion Estimation Formula:

Transformation:

Rank assigned to ties:
Normal

Blom's

Standardized values

Mean

\section{Frequency histograms}

To plot the frequency, for each feature histograms were employed:

a) data discretization

b) frequency

c) frequency plot; column height is proportional to frequency

These statistics were developed using the SPSS 13.0 software. The technical settings are as follows:

For the variables one of geophysical feature was selected; the number of columns was defined by the rule of population $<=2 n, n=$ the number of columns. Eleven columns were used in every case, since the population was around 1800. This does not represent the entire population: a selection had to be made, so in order to achieve a reasonable result, only the values from permeable units were selected.

\section{Further aspects of the analysis}

Definition of mode: in an ideal case there is only a single peak. Geologic applications use mode as the forming process of values. Thus, unimodal refers to the mode formed by a homogeneous process. In the case of multimodal distribution, all that can be stated is that there is more than one process involved. 


\section{Covariance}

Covariance was used to analyze the correlation in the data. This is one of the most fundamental statistics to show how tight the relationship between two variables can be. It is important (Geiger 2007) because:

- the (negative or positive) sign shows the direction of connection

- its value is independent of the order of variables,

- if the value is 0 , it means that there is no connection, and

- it can lead to either a negative or a positive result.

$$
\operatorname{Cov}(x, y)=\sum_{i}^{n}\left(x_{i}-\bar{x}\right)\left(y_{i}-\bar{y}\right) / n
$$

\section{Factor analysis}

This is a multivariable method. It is a statistical method to describe variability among observed variables in terms of a potentially lower number of unobserved variables called factors. During the process artificial variables are generated, which express the geologic processes. The number of artificial variables depends on the number of original variables and the strength of the connection. This is a correlation matrix, which contains the connections pairwise. The values along the main diagonal are equal to one. The following formula is used to prepare the artificial variables:

$$
\mathrm{Cj}=\mathrm{b} 1 \mathrm{j} X 1+\mathrm{b} 2 \mathrm{j} X 2+\ldots+\mathrm{bnj} \mathrm{Xn} . .
$$

where

$\mathrm{Cj}=$ artificial variable $(\mathrm{j}<\mathrm{n})$

$\mathrm{X} 1 \ldots \mathrm{X} \mathrm{n}=$ the $\mathrm{n}$ pieces of samples with measured features,

$\mathrm{b} 1, \mathrm{~b} 2=$ weights applied to $\mathrm{x} 1, \mathrm{x} 2$.

During this type of analysis, the whole data table was used without the extreme values, which were selected in the EDA section of this paper. The technical parameters were as follows:

Analyze/Data Reduction/Factor Analysis

Extractions: Principal components

Number of factors: 5

Display: unrotated factor solution

Scores: regression

Options: $\quad$ excluded cases pairwise

\section{Markov analysis}

The Markov model represents one type of stochastic process model. The embedded Markov chain was used for defining the facies relationships. It is based on information from the A-993 core description. The embedded type of Markov chain does not take into consideration the thickness of the beds, nor the 
rate of deposition. It deals only with the order of the beds. The model does not contain every lithological type. The conditions for its use in stratigraphy are:

- no hiatus is permitted, and

- the number of states is independent and finite.

$$
\text { rij }=0 \text {, rij }=\text { Pij/-pii, if } \mathrm{i} \neq \mathrm{j}
$$

Vertical facies definition

The Golden Software Strater program was used to plot the vertical sedimentary facies. A table was constructed containing the following parameters: hole ID, intervals (from- to), lithology keywords, lithological description and indent percentages (the latter term is from the Strater software, and refers to numbers proportional to the lithology type's grain size). Ten lithology types were defined.

\section{3-D mega-sedimentological modeling}

Model building begins with interpolation of the stratigraphic system boundaries between the information source points. Top and base maps are created during this process. Thus every stratigraphic unit can be placed in its correct spatial location. The modeling software uses grid systems. Every grid block has $X, Y$, and $Z$ coordinates. It is possible to obtain a column of equal rectangles if every grid block is of the same scale. The result is the chosen stratigraphic unit filled by grid blocks. This is the principals of geocellular models; this model is called a frame model. The challenge is to populate the measured features into the 3-D model. At this point every grid block at well locations has 4 values: X, Y, Z coordinates and a properties value. To describe the desired features in space (Seller and Földes 1992), it is necessary to make predictive property maps for every stratigraphic unit, and place it within the model framework. The solution is spatial kriging (Jones 1992), according to which the view of the model is defined by the model framework as well as by stratigraphic correlation (Geiger 2002). The 3-D definition of the depositional environment is obtained by mapping the sedimentary facies (Geiger 2002).

The 3-D modeling steps (Geiger et al. 2002) are:

- definition of the sedimentary facies,

- definition of the form of deposition (granulometric composition) (Geiger 1981, 1986),

- areal extension of the sedimentary facies, provided the depositional mode and sedimentary facies are correctly correlated,

- the model can be extended to the zones without physical core material by calibrating the geophysical logs and the core material (Révész 1980a, b), and 
- after defining the sand content based on the calibrated well log and mapping it, the resulting contours represent the depositional environment (Geiger 2002).

If the 5th step is repeated at tight depth intervals, a 3-D shape of the depositional environment is obtained (Geiger 2002).

In order to achieve this it is important to choose the appropriate time horizon. In delta environments it is possible to use the horizontal clay marls. This level is considered the $0 \mathrm{~m}$ level, from which horizontal sections can be made. The distance between these layers in the introduced model is $0.4 \mathrm{~m}$.

\section{Results}

The A-993 core is not described in detail here; however, it is correctly shown (Fig. 3). This is one of the longest cores cut in the Ap-13 reservoir, which it represents vertically in its entirety. Parts of the core are unstructured, compact, or collapsed; there are also parts which can be defined as thin-layered turbidites or slumps. The entire core shows a fining-upward nature. In the thicker sand beds imbricated clay pebbles, or clay intraclasts and amalgamation surfaces could be recognized. The thinly-layered parts of the core show deformation structures such as load casts, erosion structures as sole marks and sharp transitions. At the base it is possible to identify the lower oil contact.

\section{Statistical analysis}

Table 1 shows the statistical parameters of the sand and shale content, permeability, porosity and bound water saturation.

Table 1

Statistical properties

\begin{tabular}{|l|l|l|l|l|}
\hline & \multicolumn{1}{|c|}{ Mean } & \multicolumn{1}{|c|}{$\begin{array}{c}\text { Confidence interval } \\
95 \% \text { for mean }\end{array}$} & \multicolumn{1}{|c|}{ Median } & Variance \\
\hline $\begin{array}{l}\text { VSND } \\
\%(\mathrm{~V} / \mathrm{V})\end{array}$ & 63.7 (std. error: 0.196) & $63.31-64.08$ & 64.38 & 69.45 \\
\hline $\begin{array}{l}\text { VSHA } \\
\%(\mathrm{~V} / \mathrm{V})\end{array}$ & 17.66 (std. error: 0.192) & $17.28-18.04$ & 16.94 & 67.57 \\
\hline $\begin{array}{l}\text { FIAP } \\
\%(\mathrm{~V} / \mathrm{V})\end{array}$ & 17.01 (std. error: 0.059) & $16.89-17.13$ & 17.24 & 6.37 \\
\hline $\begin{array}{l}\text { PERM } \\
\text { mD }\end{array}$ & 29.58 (std. error: 0.82$)$ & $28.21-31.45$ & 16.83 & 1234.218 \\
\hline $\begin{array}{l}\text { SWAP } \\
\%(\mathrm{~V} / \mathrm{V})\end{array}$ & 59.97 (std. error: 0.52$)$ & $58.95-61.00$ & 54.58 & 494.36 \\
\hline
\end{tabular}




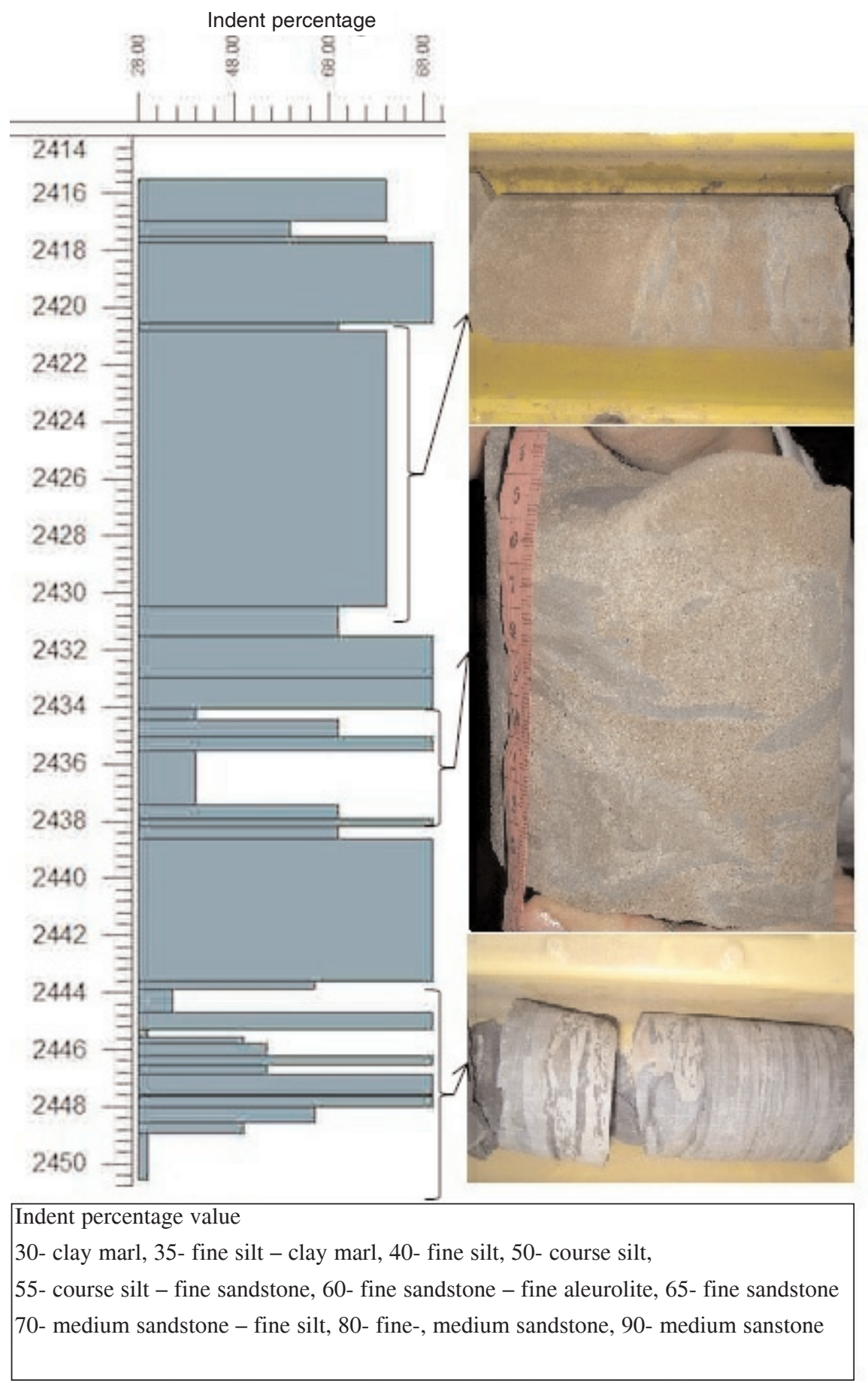

Central European Geology 54, 2011 
None of the distributions are normal (Fig. 4), and the permeability distribution is lognormal.

Normal Q-Q Plot of VSND
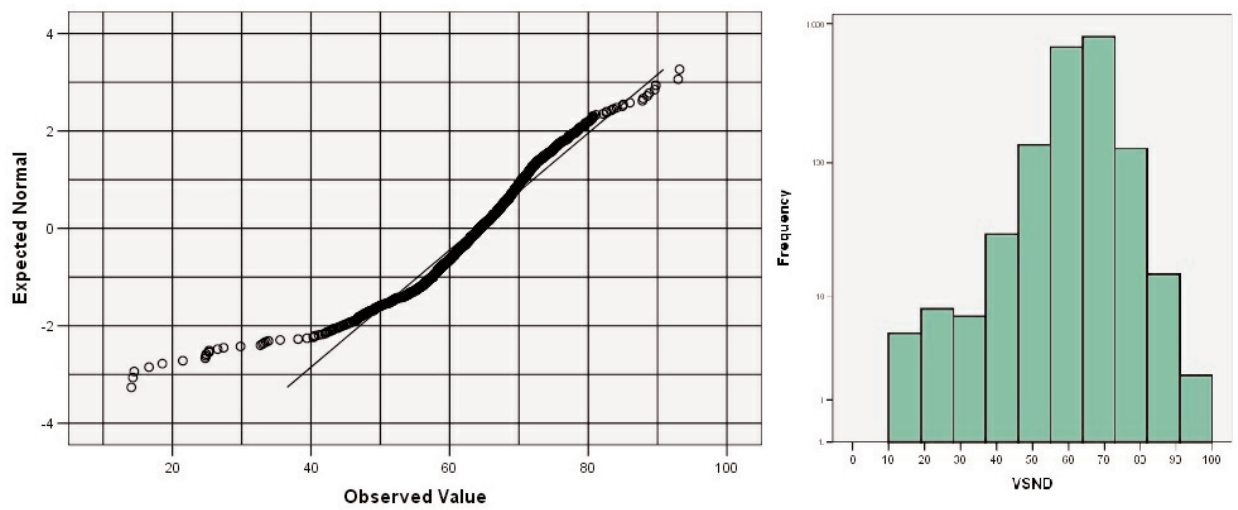

Fig. 4

Histogram and Q-Q plot of sand content

Factor analysis

The component matrix and the total variance table (Table 2) show the following:

The first component indicates a process whereby the sand content and the porosity increase, and the shale content and bound water saturation decrease. This can be explained by an increased influence of channel deposits.

Table 2

Component matrix and total variance

\begin{tabular}{|c|c|c|c|c|c|c|c|c|c|}
\hline \multicolumn{6}{|c|}{ Component Matrix (a) } & \multicolumn{4}{|c|}{ Total variance } \\
\hline & \multicolumn{5}{|c|}{ Component } & \multirow{2}{*}{ Component } & \multicolumn{3}{|c|}{ Initial Eigenvalues } \\
\hline & 1 & 2 & 3 & 4 & 5 & & Total & $\%$ of Variance & Cumulative $\%$ \\
\hline PERM & & .715 & & & & 1 & 3.873 & 77.452 & 77.452 \\
\hline SWAP & -.835 & & .537 & & & 2 & .685 & 13.695 & 91.147 \\
\hline FLAP & .972 & & & .206 & & 3 & .363 & 7.257 & 98.404 \\
\hline VSHA & -.945 & & & & .106 & 4 & .059 & 1.173 & 99.576 \\
\hline VSND & .942 & & & & .100 & 5 & .021 & .424 & 100.000 \\
\hline \multicolumn{6}{|c|}{ Extraction Method: Principal Component Analysis. } & & & & \\
\hline \multicolumn{6}{|c|}{ a 5 components extracted. } & & & & \\
\hline
\end{tabular}

$\leftarrow$ Fig. 3

Vertical facies column of the A-993 core with specific photos 
The second process is deals with a feature which was not measured, but causes permeability to increase. This is a sorting process for the system.

The third concerns grain size fining.

The fourth component's variance and the value in the matrix are small; thus there is not much confidence in the forming process. One explanation for the increase in porosity can be the secondary dissolution of the feldspar grains.

The fifth process is as uncertain as the fourth. A possible reason for the increase in sand and shale content at the same time is the influence of turbiditic flow.

\section{Covariance}

The covariance matrix (Table 3) shows the connections between the properties by values, and Figure 5 shows it as a figure for better understanding.

Table 3

Covariance

\begin{tabular}{|l|r|r|r|r|r|r|}
\hline & \multicolumn{1}{|c|}{ FIAP } & \multicolumn{1}{c|}{ PERM } & \multicolumn{1}{c|}{ SWAP } & \multicolumn{1}{c|}{ VSHA } & \multicolumn{1}{c|}{ VSND } & Population \\
\hline FIAP & 6.294 & 63.596 & -31.509 & -11.855 & 10.907 & 1806 \\
\hline PERM & 63.596 & 1234.218 & -367.087 & -157.588 & 128.514 & 1806 \\
\hline SWAP & -31.509 & -367.087 & 494.383 & 85.340 & -68.836 & 1806 \\
\hline VSHA & -11.855 & -157.688 & 85.340 & 67.575 & -45.320 & 1806 \\
\hline VSND & 10.907 & 128.514 & -68.836 & -45.320 & 69.457 & 1806 \\
\hline
\end{tabular}

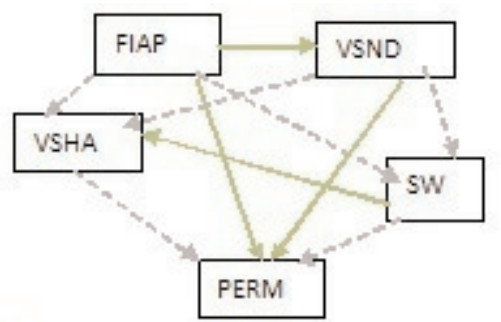

Fig. 5

Properties connections

This figure shows the reservoir parameter connections in the examined system. A simple lines indicates a positive relationship, and the stripped lines shows negative influences. Thus porosity and sand content, or porosity and permeability, have positive connections, as do sand content and permeability or water saturation and shale content. Other connections can be characterized with negative relationships, such as porosity and shale content, shale content and permeability, sand content and shale content, water saturation and porosity, or permeability and water saturation. 


\section{Markov analysis}

The result of Markov analysis (Table 4) is merely informative; it contains considerable uncertainty because of the small number of samples.

Table 4

Differential matrix without zero values

\begin{tabular}{|l|l|l|l|l|l|l|}
\hline & $\begin{array}{l}\text { Clay } \\
\text { marl }\end{array}$ & Silt & $\begin{array}{l}\text { Fine sand } \\
\text { stone and silt }\end{array}$ & $\begin{array}{l}\text { Medium } \\
\text { sand stone } \\
\text { and silt }\end{array}$ & $\begin{array}{l}\text { Fine and } \\
\text { medium } \\
\text { sand stone }\end{array}$ & $\begin{array}{l}\text { Medium } \\
\text { sand } \\
\text { stone }\end{array}$ \\
\hline Clay marl & & 0.283 & & & & 0.152 \\
\hline Silt & 0.057 & & & & & 0.419 \\
\hline $\begin{array}{l}\text { Fine sand } \\
\text { stone and } \\
\text { silt }\end{array}$ & & 0.116 & & & 0.203 & \\
\hline $\begin{array}{l}\text { Medium } \\
\text { sand stone } \\
\text { and silt }\end{array}$ & & 0.273 & & & 0.114 & \\
\hline $\begin{array}{l}\text { Fine and } \\
\text { medium } \\
\text { sand stone }\end{array}$ & & 0.87 & & 0.222 & & \\
\hline $\begin{array}{l}\text { Medium } \\
\text { sand stone }\end{array}$ & 0.056 & & 0.056 & & & \\
\hline
\end{tabular}

Thus the sedimentary cycle framework (Fig. 6) is: Unlayered clay marl $\rightarrow$ silt $\rightarrow$ medium-grain sandstone $\rightarrow$ unlayered clay marl. Not all of the lithology types are included.

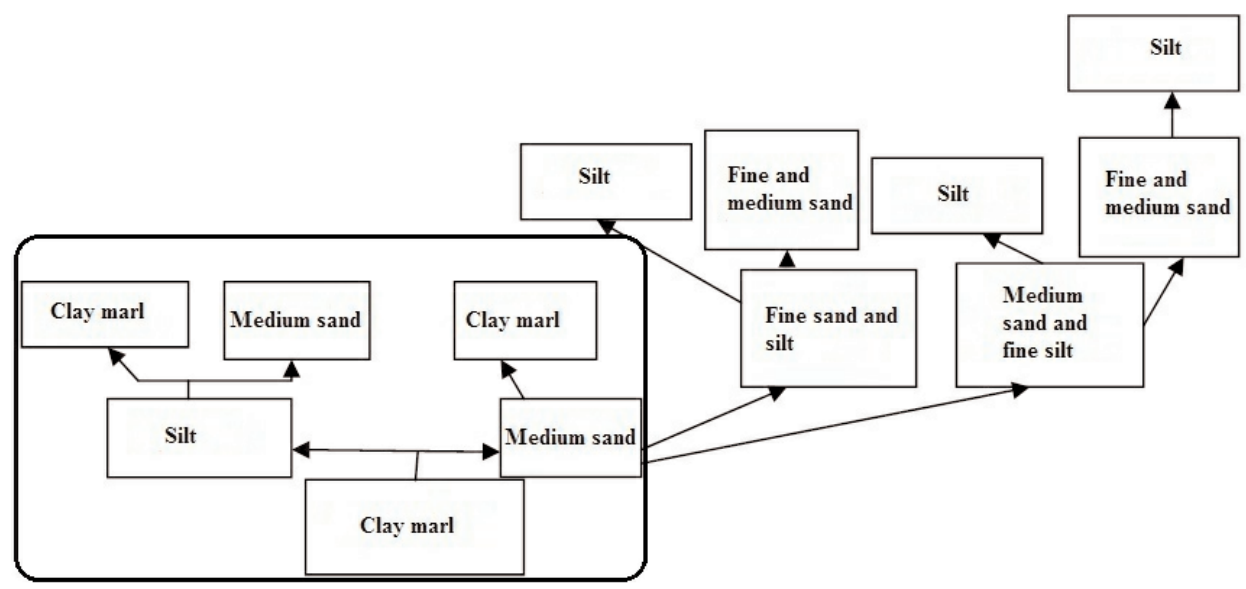

Fig. 6

Facies connection diagram 


\section{3-D model}

The 3dimensional shape of the reservoir, with sand content, definitely shows (Fig. 7) that the reservoir is thinning from north to south. The highest sand contents are at the top and in the deeper northern part of the reservoir. They are separated by beds with lesser sand content.

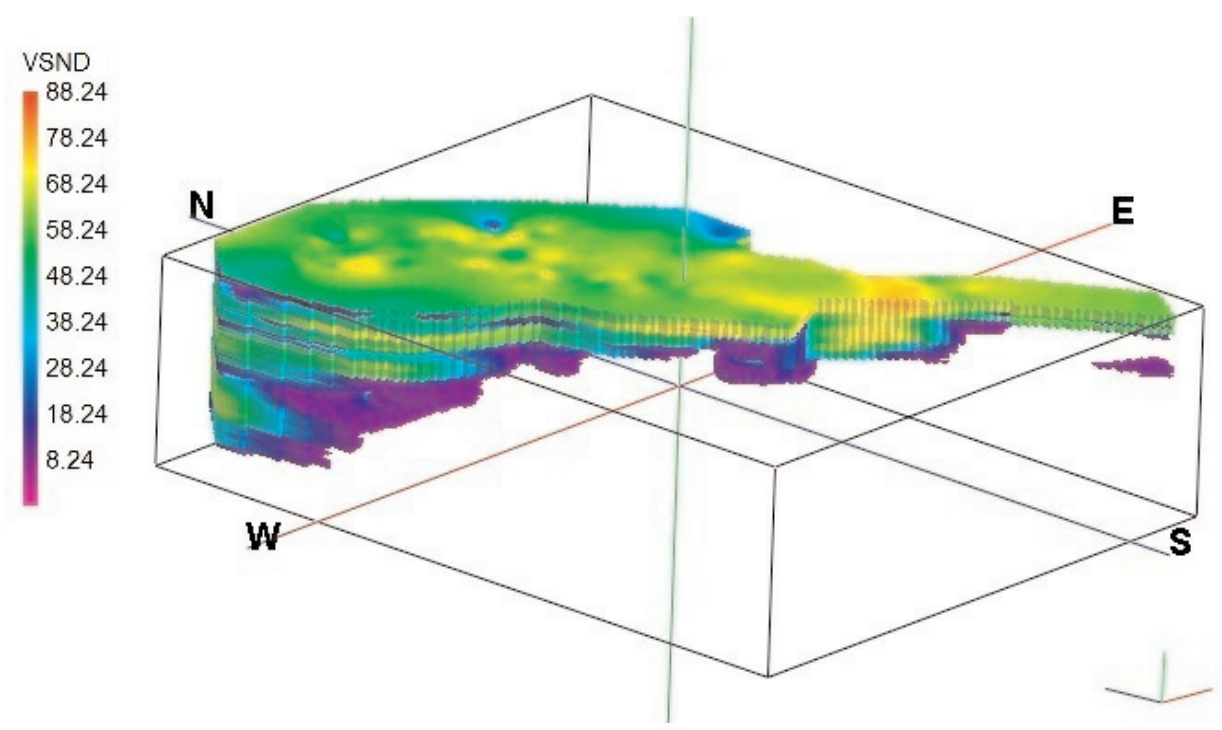

Fig. 7

3-D model of sand content

The cross-sections (Fig. 8) were made using Rock Works 15. These figures show the studied core (well A-993) as well as the sand content and porosity distribution.

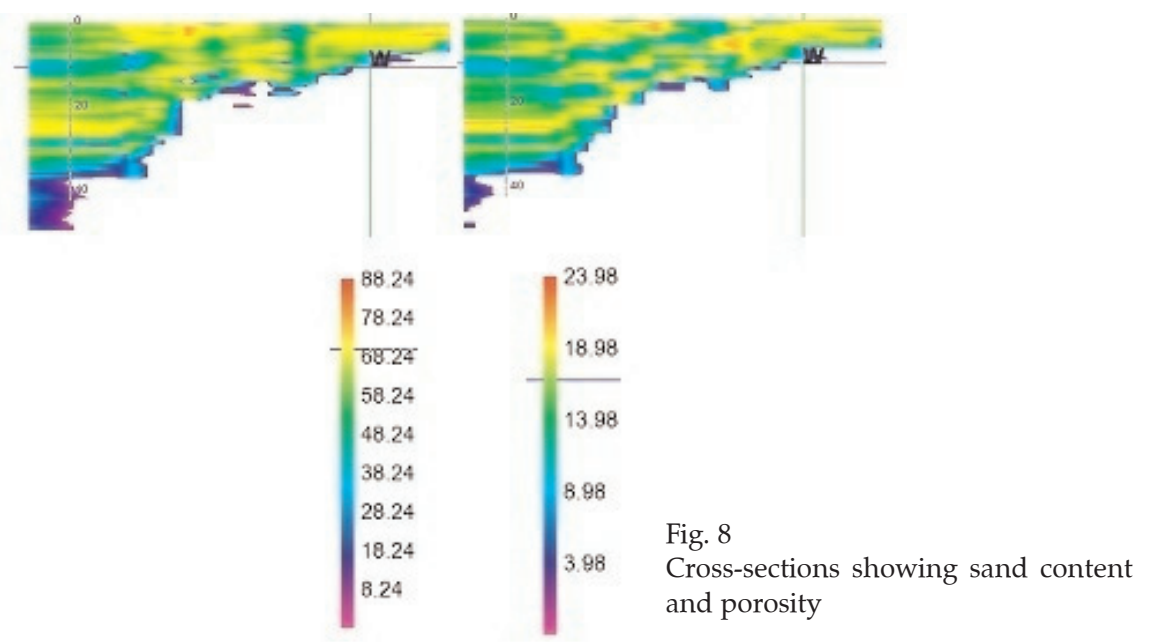


The high porosity values appear where sand content increases. The highest sand contents have porosity values of around $20-24 \mathrm{vol} \%$. The cross-sections underscore the main characteristic of this area (prograding lobes).

\section{Results, discussion and conclusions}

Based on the obtained results, the studied reservoir represents a deep-marine clastic system, with $30-70 \%$ sand content, presenting the characteristic of prograding lobes (Fig. 9).

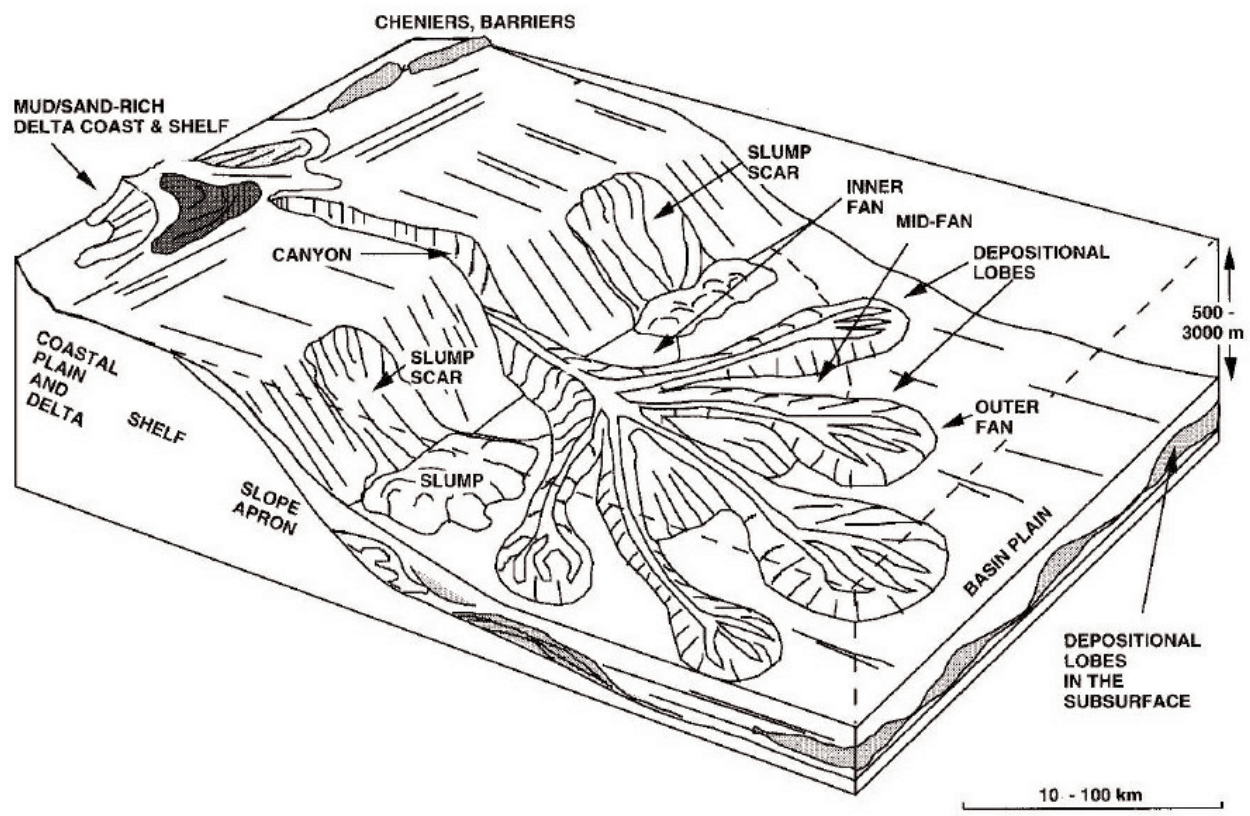

Fig. 9

Mud-sand-rich submarine fans (Reading and Richards 1994)

Based on the factor analysis results the main process involved is the extension of the delta system; the smaller processes are the migration of sand bodies through turbiditic flows. The vertical facies column (which was based on the core description) is appended to the 3-D model section (Fig. 10), underlining their mutual similarity.

The vertical facies column supports the model of a mud/sand-rich submarine fan system. These clastic systems are of medium size (area: $560 \mathrm{~km}^{2}-44000 \mathrm{~km}^{2}$, volume: $75-3000 \mathrm{~km}^{3}$, radius: $10-450 \mathrm{~km}$ ).

The middle fan can be recognized by its convex shape in cross-section, a morphological shape (suprafan lobes) named by Normark (1970). 


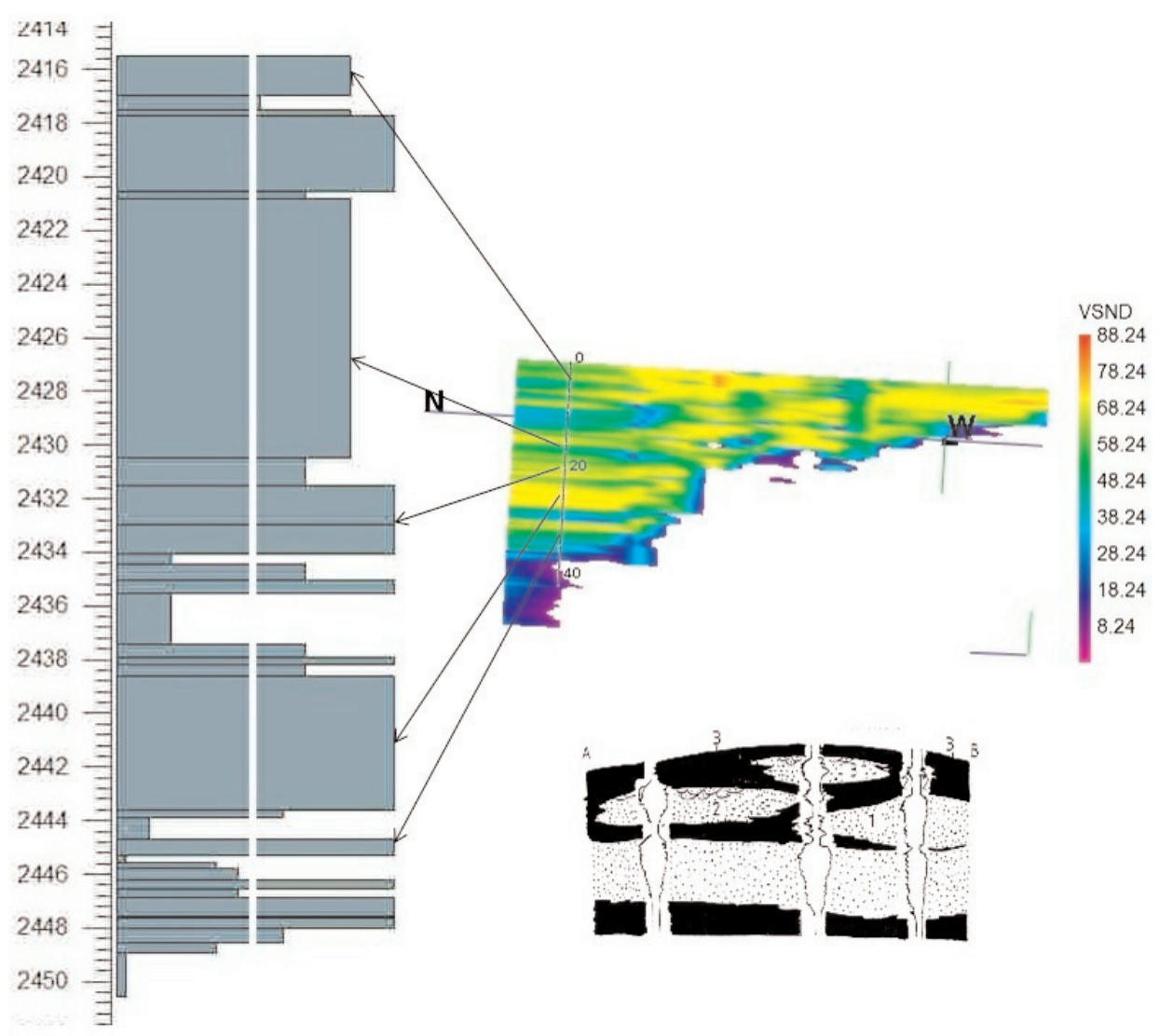

Fig. 10

3-D model W-E section, with location of the A-993 well and the hypothetical prograding alluvial fan (Walker 1978)

\section{References}

Bérczi, I. 1969: Az algyői felsôpannóniai homokkő összlet üledékföldtani vizsgálata (Sedimentological analysis of the upper-pannonian sanstone of Algyő). - Földt. Közl., 99/4, pp. 337-350.

Bérczi, I. 1988: Preliminary Sedimentological Investigations of Neogene Depression in the Great Hungarian Plain. - In: Royden, L.H., F. Horváth (Eds): The Pannonian Basin - a Study in Basin Evolution. - AAPG Memoir 45, pp. 107-116.

Geiger, J. 1981: Diagenetizált törmelékes üledékek szemcseeloszlásának ősföldrajzi értékelése: A Szeged-2 telep vizsgálata (Paleogeographical assesment of the deformated clastic sediment's 
grain's distribution: The analysis of Szeged-2 reservoir.). - A Magyar Szénhidrogénipari KutatóFejlesztő Intézet Múszaki-Tudományos Közleményei I, pp. 5-11, Budapest.

Geiger, J. 1986: Üledékes homokkőtestek szöveti és morfogenetikai vizsgálata (The texture and morphogenetical analysis of sedimentary sand bodies). - Földt. Közl., 116/3, pp. 249-266.

Geiger, J. 2002: A Pannóniai Újfalui (Törteli) Formációban levő Algyő-Delta Fejlődéstörténet.: Az Algyő-Delta Alkörnyezeteinek 3d Modelezése (The Algyő-Delta geologic evolution in the Pannónian (Újfalu and Törtel) Formation: The 3d modelling of the Algyő-Delta subenvironment ). - Földt. Közl., 133/1, pp. 91-112.

Geiger, J. 2007: Geomatematika (Geomathematics). - JATEPress, Szeged.

Geiger, J., Kiss B.-né 1995: Az Algyő-1 telep gázfázisának 3-D rezervoár geológiai modelje a Szeged-1 analógiájának felhasználásával (The reservoir geological modell of the gas phase of Algyő-1 reservoir with the analogy of Szeged-1 reservoir). - KUMMI Jelentés, 105 p. Tsz. 102-323.

Geiger. J., J. Komlósi 1991: Az Algyő-2 telep DK-i részének rezervoár geológiája (Geology of SouthEast of Algyó-2 reservoir). - OGIL Jelentés 110 p. Tsz. 115-130.

Geiger, J., J. Komlósi 1993: 3-D szedimentológiai rezervoárgeológiai modelalkotás törmelékes tárolókban (3-D sedimentological reservoir modelling in clastic reservoirs). - OMBKE XII. Vándorgyulés és Kiállítás. Proceedings. B2. 1-11. Montan Press. Budapest.

Geiger, J., J. Komlósi 1995a: Első lépések egy integrált szedimentológiai-geomatematikai 3-D modellező rendszer felé törmelékes tárolókban (First steps for creating an integrated sedimentological-geomathematical 3-D modelling system in a clastic reservoir). - A IV. Geomatematikai Ankét Előadásai, MTF. Szeged, pp. 31-47.

Geiger, J., J. Komlósi 1995b: 3-D geological simulation of a deltaic reservoir in Hungary. - AAPG Congress. 1995. Nice, Proceedings, pp. 65-87.

Geiger, J., J. Komlósi 1996: Szedimentológiai geomatematiaki 3-Dmodellező rendszer törmelékes $\mathrm{CH}$-tárolókban (Sedimentologic, geomathematical 3-D modeller system in clastic $\mathrm{CH}$ reservoirs). - Kőolaj és Földgáz, 1996/2, pp. 53-81.

Geiger, J., I. Révész 1992: Az Algyő-1 telep DK-i részének szedimentológiai vizsgálata (The sedimentological analysis of South-East part of Algyő-1 reservoir). - SZKFI Jelentés, 130 p. Tsz. $143-21$.

Hniszné, O.M. 1996: Az Ap-13 telep rezervoárgeológiai feldolgozása (The reservoir geological treatment of Ap-13 reservoir). - Jelentés. Irattár.

Jones, T.A. 1992: Extension to three dimension: introduction to the section on 3-D geologic block modeling. - In: Hamilton, D.E., T.A. Jones (Eds): Computer modeling of geological surfaces and volumes. - AAPG Computer Applications in Geology. 1, 175 p.

Magyar, I. 2010: A Pannon-medence ősföldrajza és környezeti viszonyai a késố miocénben (The paleogeography and the environment relation of the Pannon-basin in the late miocene). GeoLitera Kiadó, Szeged, pp. 72-73.

Mucsi, M., J. Geiger 1989: Az algyői Alsópannon-13. sz. telep üledékföldtani vizsgálata az A-922 és A-937. sz fúrások magmintái alapján (The Alsópannon 13. reservoir sedimentological examination in Algyő, according to the A-922 and the A- 937 cores). - SZKFI Jelentés. Sz.sz: 22941-220. Irattár.

Mucsi, M. 1973: A Dél-Alföld földtani fejlődéstörténete a neogénben (The South-Plain geological evolution in the Neogene). - Földt. Közl., 103, pp. 311-318.

Normark, W. R. 1970: Growth patterns of deep sea fans. - AAPG Bulletin, 54, pp. 2170-2195.

Reading, H.G., M. Richards 1994: Turbidite systems in deep-water basin margins classified by grain size and feeder system. - Bull. Am. Ass. Petrol. Geol., 78, pp. 792-822.

Révész, I. 1976: Az algyői Maros telepek üledékföldtani heterogenitása és ôsföldrajzi viszonyai (The sedimentological heterogenity and paleogeography of Maros reservoir at Algyő filed). - OGIL jelentés. Adattár.

Révész, I. 1977: Az algyői Algyő-2 telep üledékföldtani heterogenitása és ősföldrajzi viszonyai (The sedimentological heterogenity and paleogeography of Algyő-2). - OGIL jelentés. Adattár. 
Révész, I. 1979: Az algyői Algyő-1 telep üledékföldtani heterogenitása és ősföldrajzi viszonyai (The sedimentological heterogenity and paleogeography of Algyő-1 reservoir at Algyő filed). - OGIL jelentés. Adattár.

Révész, I. 1980a: Az Algyő-2 telep földtani felépítése, üledékföldtani heterogenitása és ősföldrajzi viszonyai (The sedimentological heterogenity, geology and paleogeography of Algyő-2 reservoir at Algyő filed). - Földt. Közl., 110, pp. 512-539.

Révész, I. 1980b: Az algyői Szeged-1 telep üledékföldtani heterogenitása és ősföldrajzi viszonyai (The sedimentological heterogenity and paleogeography of Szeged-1 reservoir at Algyő filed). OGIL jelentés. Adattár.

Seller, Zs., T. Földes 1992: 3-D lithostratigraphic modeling. - EAGE 54rd Meeting and Technical Exhibition, France.

Walker, R.G. 1978: Deep-water sandstone facies and submarine fans: models for exploration for stratigraphic traps. - AAPG Bulletin, 62, pp. 932-966. 